A C G

publications

Org. Commun. 14:3 (2021) 240-254

organic

communications

\title{
Waste to wealth: agro-waste catalyzed green method synthesis of
} 5-aryl-1,2,4-triazolidine-3-thiones and 1,2,4-triazospiro-3-thiones

\author{
Santosh Y. Khatavi ${ }^{*}$ and Kamanna Kantharaju \\ Department of Chemistry, Peptide and Medicinal Chemistry Research Laboratory, \\ Rani Channamma University, Belagavi, P-B, NH-4-591156, Karnataka
}

(Received April 14, 2021; Revised June 14, 2021; Accepted July 16, 2021)

\begin{abstract}
This paper describes novel agro-waste derived Water Extract of Orange Fruit Shell Ash (WEOFSA) catalyzed synthesis of 5-aryl-1,2,4-triazolidine-3-thiones and 1,2,4-triazospiro-3-thiones under microwave irradiation. Herein, we have developed inexpensive, facile and green method synthesis of cyclic thiones by the reaction of aromatic aldehyde and cyclic ketone, with thiosemicarbazide in presence of agro-waste derived catalyst. The obtained product is chromatographically pure after recrystallization from ethanol, and final product is characterized by various spectroscopic techniques FT-IR, ${ }^{1} \mathrm{H}-,{ }^{13} \mathrm{C}-\mathrm{NMR}$ and HR-MS.
\end{abstract}

Keywords: Agro-waste; green method; cyclic ketone; semicarbazide; microwave. @ 2021 ACG Publications. All rights reserved.

\section{Introduction}

The chemistry of heterocyclic is a promising area of research in the organic chemistry ${ }^{1}$, due to the vast number of molecules emerged blockbuster lifesaving drug candidates ${ }^{2-3}$. The triazole heterocycle chemistry occupied an important place, due to their wide range of biological applications exhibited ${ }^{4-5}$. Further, the chemistry of 1,2,4-triazoles and their fused heterocycle has received considerable attention owing to their simple synthetic and effective biological importance ${ }^{6}$. Triazole is a five-membered heterocycle having three nitrogen, two carbon atoms and two double bonds having general formula $\mathrm{C}_{2} \mathrm{H}_{3} \mathrm{~N}_{3}{ }^{7}$, and exhibited two isomeric forms 1,2,3-triazole and 1,2,4-triazole (Figure 1) ${ }^{8}$, but later one isomeric form has<smiles>c1c[nH]nn1</smiles>

1,2,3-triazole<smiles>c1c[nH]cn1</smiles>

1,2,4-triazole

Figure 1. Two isomeric structure of triazoles

found diverse synthetic and biological applications ${ }^{7}$. A large number of 1,2,4-triazole containing ring system have been reported their wide range of pharmacological applications including CNS stimulants ${ }^{9}$, sedatives ${ }^{10}$, anti-inflammatory ${ }^{11}$, anti-microbial agents ${ }^{12}$, anti-anxiety and anti-mycotic activity such as Intraconazole ${ }^{13}$, Fluconazole and Voriconazole ${ }^{14-15}$. In addition, some of the recent using drugs containing 1,2,4-triazole group are; Triazolam ${ }^{16}$, Alprazolam $^{17}$, Etizolam and Furacylin ${ }^{18-19}$ (Figure 2).

\footnotetext{
* Corresponding author: E-Mail: kk@rcub.ac.in 
Khatavi and Kantharaju Org. Commun. (2021) 14:3 240-254

The sulphur containing heterocycle represented important practical applications in mycobacterial and hypoglycemic treatment ${ }^{20-22}$. Among these heterocycle of mercapto and thione-substituted 1,2,4-triazole ring systems showed variety of pharmacological applications have been reported ${ }^{23}$, anti-cancer ${ }^{24}$ and anti-HIV. Addition to these important bioactive applications, mercapto-1,2,4-triazoles are also greater utility in the preparative organic chemistry ${ }^{25}$, for example in the preparation of thiazolotriazoles ${ }^{26}$, triazolothiadiazoles ${ }^{27}$, triazolothiazines ${ }^{28}$, triazolothiazepines and triazolothiadiazines ${ }^{29}$.

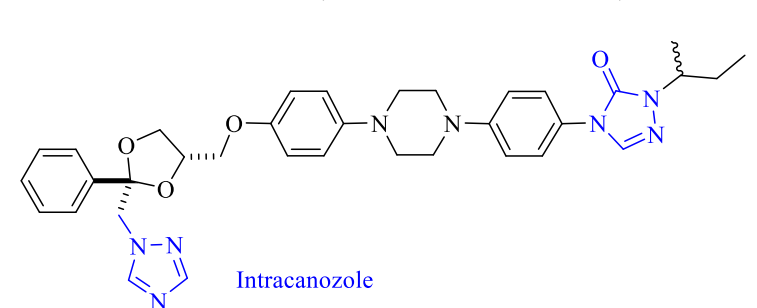

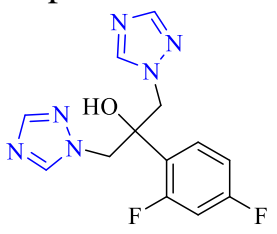

Fluconazole

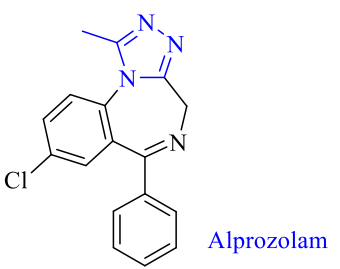

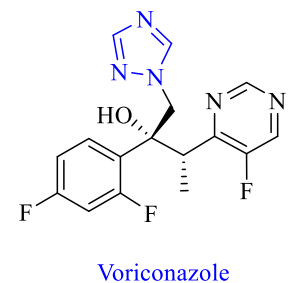

Voriconazole

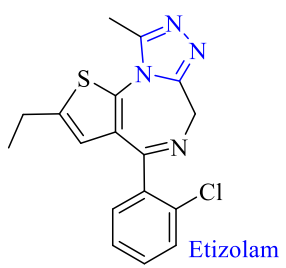

Figure 2. Some drug molecules containing triazole moieties

Nowadays chemist are exploring alternative synthetic route to conventional or existing, to overcome hazardous and harmful use of organic solvent or catalyst ${ }^{30}$. The synthetic route is environmentally benign for the privileged 'drug-like' heterocycle synthesis from readily available precursors with green catalyst is substantial utility in academia as well as in the industrial research ${ }^{31}$. In recent years, chemist have on track to replace hazardous and volatile organic solvent used in reaction media to develop sustainable alternative greener solvent such as $\mathrm{PEG}^{32}$, water ${ }^{33}$, ionic liquids ${ }^{34}$, agrowaste extract ${ }^{35}$ and solvent-free condition ${ }^{36}$. In addition, a catalyst-free synthetic route is one of the remarkable tool in scientific society, because they are associated with minimization of pollution, cost and impurity ${ }^{37}$.

In recent year's chemist are demonstrated alternative catalytic media derived from agro-waste extraction and employed preparation of valuable organic transformations ${ }^{38}$. The advantage of using alternative these agro-waste based media showed its non-toxicity, bio-compatibility and solubility of reactants. Some of the agro-waste based media have been employed in organic transformation includes oxidation and reduction reactions ${ }^{39}$, Heck reaction ${ }^{40}$, substitution reactions, Suzuki cross-coupling reaction, Henry reactions, Sonogashira reaction, and Hiyama cross-coupling.

The hetero-cyclization of readily existing linear compounds is one of the most common and admired line of synthesizing valuable heterocycles ${ }^{41}$. Several synthetic and natural heterocyclic bioactive molecules have been demonstrated as a potential drug material ${ }^{42,43}$. One of its kind heterocycle 1,2,4-triazoles synthesis has attracted wide spread attention, due to their additional agrochemical properties such as insecticidal ${ }^{44}$, fungicidal ${ }^{45}$, herbicidal ${ }^{46}$ bactericidal $^{47}$ and industrial dyes ${ }^{48}$, lubricants ${ }^{49}$ and analytical reagents ${ }^{50}$. Researcher demonstrated these derivatives can be easily transformed to 1,2,4-triazoles, which are more potent. To the best of our knowledge, a very few synthetic methods are available in the literature for the synthesis of 1,2,4-triazoles. Due to pharmacological significance and agrochemical application of the 5-aryl-1,2,4-triazolidine-3-thiones and 1,2,4triazospiro-3-thiones. Various research groups are striving to make the synthetic method more easy, ecofriendly and greener method. There are some literature reports are available employing sulphamic acid, 4-dimethylaminopyridine (DMAP) ${ }^{51}$, presence of ionic liquid $\left[\mathrm{C}_{16} \mathrm{MPy}\right] \mathrm{AlCl}_{3}, 25 \%$ ethanol @ $80{ }^{\circ} \mathrm{C}$, $80 \%$ Acetic acid and $\mathrm{CoFe}_{2} \mathrm{O}_{4} @ \mathrm{SiO}_{2}$ under room temperature stirring condition, ionic liquids $\left[(\mathrm{Py})_{2} \mathrm{SO}_{[}\left[\mathrm{HSO}_{4}\right]\right.$ in ethanol, and PEG-400 under room temperature stirring condition. In this paper, we wish to account agro-waste extract of WEOFSA as a potential greener catalytic solvent media for the 
Waste to wealth: agro-waste catalyzed green method

synthesis of a diverse 1,2,4-triazolidine-3-thione and 1,2,4-triazospiro-3-thione derivatives from substituted aromatic aldehyde and thiosemicarbazide under microwave irradiation condition.

\section{Experimental}

\subsection{Materials and Methods}

All the reagents are used in the synthesis are purchased from Sd-fine chemicals and were used without further purification. Custom made microwave oven having facility to fit reflux condenser and magnetically stirrer is used for the irradiation reaction at power of $450 \mathrm{~W}$. The melting points were determined by the open capillary method and are uncorrected. The WEOFSA solution is subjected to elemental analysis by the ESICO Microprocessor Flame Photometry model 1382. The ash powder subjected to EDX and SEM and obtained by CARL ZEISS OXFORD instrument, Japan. FT-IR spectra were measured with Thermo Fischer scientific using $\mathrm{KBr}$ pellet method, ${ }^{1} \mathrm{H}-,{ }^{13} \mathrm{C}-\mathrm{NMR}$ spectra were collected in DMSO- $d_{6}$ on Agilent spectrometer at $400 \mathrm{MHz}$. The chemical shifts are reported in ppm $(\delta)$ relative to tetramethylsilane as internal standard. The molecular weight is analyzed by HR-MS(ESI)

\subsection{Preparation of Water Extract of Orange Fruit Shell Ash (WEOFSA)}

It is prepared by orange fruit peel (Citrus sinensis), it is collected from local area, and the peel is cleaned with distilled water, dried in sunlight and burnt them to ash on Bunsen burner, $10 \mathrm{gm}$ of the ash is soaked in $100 \mathrm{~mL}$ of double distilled water for about 2-3 h and filtered, the filtrate is termed as WEOFSA. The $\mathrm{pH}$ of the solution found to be $10.12^{45}$.

\subsection{General Procedure for Synthesis of Compounds (3a-r, 5a-e)}

In a round bottomed flask, aldehyde (1)/cyclic ketone (4) $(1 \mathrm{mmol})$, thiosemicarbazide (2) (1 $\mathrm{mmol})$ and WEOFSA $(3.5 \mathrm{~mL})$ is added. The reaction mixture is subjected to the microwave irradiation in a custom made microwave oven. After the reaction completion, diluted with distilled water $(10 \mathrm{~mL})$, filtered crude product and recrystallized with ethanol. The recrystallized product is characterized by UV-visible, FT-IR, ${ }^{1} \mathrm{H}-\mathrm{NMR},{ }^{13} \mathrm{C}-\mathrm{NMR}$ and HR-MS(ESI).

5-(4-Chlorophenyl)-1,2,4-triazolidine-3-thione ( $3 \boldsymbol{b})$ : Product white crystalline, FT-IR: $v 3438(\mathrm{NH}$ stretching), 3298 ( $\mathrm{NH}$ stretching), 3155 (C=H stretching), 1588, 1542, 1456, 1361, 1281 (C=S stretching), 1225, 1165, 1076, 1011, 935, 863, 687, $510 \mathrm{~cm}^{-1}$; ${ }^{1} \mathrm{H}-\mathrm{NMR}$ (400 MHz, DMSO- $\left.d_{6}\right): \delta 7.32$ (d, 2H, ArH, J = 8.4 Hz), $7.73(\mathrm{~d}, 2 \mathrm{H}, \mathrm{ArH}, \mathrm{J}=8.4 \mathrm{~Hz}), 8.07$ (s, 1H, CH), $8.18(\mathrm{~s}, 1 \mathrm{H}, \mathrm{NH}), 8.41(\mathrm{~s}, 1 \mathrm{H}$, $\mathrm{NH}), 11.12$ (s, 1H, NH). ${ }^{13} \mathrm{C}-\mathrm{NMR}$ (DMSO- $\left.d_{6}\right): 129.1,129.3,133.6,134.6,141.4,178.6$ ppm; HR-MS $(\mathrm{ESI}):\left(\mathrm{C}_{8} \mathrm{H}_{8} \mathrm{ClN}_{3} \mathrm{~S}\right) \mathrm{m} / z(\mathrm{Calcd})=.213.6900 \mathrm{Da} ; \mathrm{m} / z(\mathrm{Obs})=.213.6101 \mathrm{Da}$.

5-(4-Bromophenyl)-1,2,4-triazolidine-3-thione (3d):Product white crystalline, FT-IR: $v 3467$ (NH stretching), 3284 ( $\mathrm{NH}$ stretching), 3168 (CH stretching), $1659(\mathrm{C}=\mathrm{C}), 1521,1284,1394,1264$ (C=S stretching), 1148, 1080, 1062, 1016, 924, 694, $610 \mathrm{~cm}^{-1} ;{ }^{1} \mathrm{H}-\mathrm{NMR}$ (400 MHz, DMSO- $\left.d_{6}\right): \delta$ 7.56-7.58 $(\mathrm{d}, 2 \mathrm{H}, \mathrm{ArH}, J=8.4 \mathrm{~Hz}), 7.74-7.76(\mathrm{~d}, 2 \mathrm{H}, \mathrm{ArH}, J=8.4 \mathrm{~Hz}), 7.99(\mathrm{~s}, 1 \mathrm{H}, \mathrm{CH}), 8.05(\mathrm{~s}, 1 \mathrm{H}, \mathrm{NH}), 8.21$ (s, $1 \mathrm{H}, \mathrm{NH}), 11.46(\mathrm{~s}, 1 \mathrm{H}, \mathrm{NH}) ;{ }^{13} \mathrm{C}-\mathrm{NMR}\left(\mathrm{DMSO}-d_{6}\right): 128.0,134.3,136.7,138.6,146.0$ and $183.2 \mathrm{ppm}$; HR-MS (ESI): $\left(\mathrm{C}_{8} \mathrm{H}_{8} \mathrm{BrN}_{3} \mathrm{~S}\right) \mathrm{m} / z(\mathrm{Calcd})=.256.9602 \mathrm{Da} ; \mathrm{m} / z(\mathrm{Obs})=.257.9139[\mathrm{M}+\mathrm{H}]^{+} \mathrm{Da}$.

5-(4-(Trifluoromethyl) phenyl)-1,2,4-triazolidine-3-thione (3e): Product white crystalline, FT-IR: v 3433 (NH stretching), 3247 (NH stretching), 3145 ( $\mathrm{CH}$ stretching), 1657 (C=C stretching), 1528, 1459, 1358, 1326, 1250 (C=S stretching), 1162, 1064, 1012, 929, 843, 567, $523 \mathrm{~cm}^{-1} ;{ }^{1} \mathrm{H}-\mathrm{NMR}(400 \mathrm{MHz}$, DMSO- $\left.d_{6}\right): \delta 7.76(\mathrm{~d}, 2 \mathrm{H}, \mathrm{ArH}, J=8.12 \mathrm{~Hz}), 8.11(\mathrm{~d}, 2 \mathrm{H}, \mathrm{ArH}, J=8.7 \mathrm{~Hz}), 8.16(\mathrm{~s}, 1 \mathrm{H}, \mathrm{CH}), 8.19(\mathrm{~s}$, $1 \mathrm{H}, \mathrm{NH}), 8.30(\mathrm{~s}, 1 \mathrm{H}, \mathrm{NH}), 11.61(\mathrm{~s}, 1 \mathrm{H}, \mathrm{NH}) ;{ }^{13} \mathrm{C}-\mathrm{NMR}$ (DMSO- $\left.d_{6}\right): 114.2,124.6,126.2,129.2,143.5$, 164.4 and $179.2 \mathrm{ppm}$; HR-MS (ESI): $\left(\mathrm{C}_{9} \mathrm{H}_{8} \mathrm{~F}_{3} \mathrm{~N}_{3} \mathrm{~S}\right) \mathrm{m} / z($ Calcd. $)=247.2406 \mathrm{Da} ; \mathrm{m} / z(\mathrm{Obs})=$. Da. 
Khatavi and Kantharaju Org. Commun. (2021) 14:3 240-254

5-(4-Methoxyphenyl)-1,2,4-triazolidine-3-thione (3f): Product White solis, FT-IR: $v 3423$ (NH stretching), 3267 (NH stretching), 3152 (CH stretchng), 1620, 1521, 1356, 1223, 1176, 1070, 1010, 962 , 831, 602, $521 \mathrm{~cm}^{-1}$; ${ }^{1} \mathrm{H}-\mathrm{NMR}\left(400 \mathrm{MHz}, \mathrm{DMSO}-d_{6}\right): \delta 3.54\left(\mathrm{~s}, 3 \mathrm{H}, \mathrm{OCH}_{3}\right), 6.86(\mathrm{~d}, 2 \mathrm{H}, \mathrm{ArH}, J=8.7$ $\mathrm{Hz}), 7.56(\mathrm{~d}, 2 \mathrm{H}, \mathrm{ArH}, J=8.7 \mathrm{~Hz}), 7.81(\mathrm{~s}, 1 \mathrm{H}, \mathrm{CH}), 7.96(\mathrm{~s}, 1 \mathrm{H}, \mathrm{NH}), 8.21(\mathrm{~s}, 1 \mathrm{H}, \mathrm{NH}), 11.45(\mathrm{~s}, 1 \mathrm{H}$, $\mathrm{NH}) ;{ }^{13} \mathrm{C}-\mathrm{NMR}\left(\mathrm{DMSO}-d_{6}\right)$ : 55.7, 114.2, 127.2, 129.4, 142.5, 161.6, 177.9 ppm; HR-MS (ESI): $\left(\mathrm{C}_{9} \mathrm{H}_{11} \mathrm{~N}_{3} \mathrm{OS}\right) \mathrm{m} / z($ Calcd. $)=209.2700 \mathrm{Da} ; \mathrm{m} / z($ Obs. $)=209.2602 \mathrm{Da}$.

5-(p-Tolyl)-1,2,4-triazolidine-3-thione (3h):Product white crystalline, FT-IR: $v 3421$ (NH stretching), 3251 ( $\mathrm{NH}$ stretching), 3141 (CH stretching), 1589 (C=C stretching), 1547, 1458, 1359, 1301, 1248 ( $\mathrm{C}=\mathrm{S}$ stretching), 1089, 957, 816, 624, $511 \mathrm{~cm}^{-1}$; ${ }^{1} \mathrm{H}-\mathrm{NMR}$ (400 MHz, DMSO-d $): \delta 2.23\left(\mathrm{~s}, 3 \mathrm{H}, \mathrm{CH}_{3}\right), 7.31$ $(\mathrm{d}, 2 \mathrm{H}, \mathrm{ArH}, J=8.7 \mathrm{~Hz}), 7.70(\mathrm{~d}, 2 \mathrm{H}, \mathrm{ArH}, J=8.4 \mathrm{~Hz}), 7.94(\mathrm{~s}, 1 \mathrm{H}, \mathrm{CH}), 8.02(\mathrm{~s}, 1 \mathrm{H}, \mathrm{NH}), 8.16$ (s, $1 \mathrm{H}, \mathrm{NH}), 11.37(\mathrm{~s}, 1 \mathrm{H}, \mathrm{NH}) ;{ }^{13} \mathrm{C}-\mathrm{NMR}$ (DMSO- $\left.d_{6}\right): 23.6,126.7,125.6,129.4,139.5,146.5$ and 176.2 ppm; HR-MS(ESI): $\left(\mathrm{C}_{9} \mathrm{H}_{11} \mathrm{~N}_{3} \mathrm{~S}\right) \mathrm{m} / z($ Calcd. $)=193.2756 \mathrm{Da} ; \mathrm{m} / z$ (Obs. $)=193.5152 \mathrm{Da}$.

5-(4-Nitrophenyl)-1,2,4-triazolidine-3-thione (3j): Product yellow solid, FT-IR: $v 3341$ (NH stretching), 3145 ( $\mathrm{NH}$ stretching), 2983 (CH stretching), 1589 (C=C stretching), 1539, 1441, 1391, 1271 (C=S stretching), 1194, 1071, 1002, 923, 855, 692, $508 \mathrm{~cm}^{-1}$; ${ }^{1} \mathrm{H}-\mathrm{NMR}\left(400 \mathrm{MHz}, \mathrm{DMSO}-d_{6}\right): \delta 7.53(\mathrm{~d}, 2 \mathrm{H}$, $\operatorname{ArH}, J=6.9 \mathrm{~Hz}), 7.76(\mathrm{~d}, 2 \mathrm{H}, \mathrm{ArH}, J=6.9 \mathrm{~Hz}), 8.02(\mathrm{~s}, 1 \mathrm{H}, \mathrm{CH}), 8.07(\mathrm{~s}, 1 \mathrm{H}, \mathrm{NH}), 8.32(\mathrm{~s}, 1 \mathrm{H}, \mathrm{NH})$, $11.48(\mathrm{~s}, 1 \mathrm{H}, \mathrm{NH}) ;{ }^{13} \mathrm{C}-\mathrm{NMR}$ (DMSO- $\left.d_{6}\right): 127.7,128.5,132.8,134.2,142.8$ and $179.7 \mathrm{ppm}$; ESIMS: $\left(\mathrm{C}_{8} \mathrm{H}_{8} \mathrm{~N}_{4} \mathrm{O}_{2} \mathrm{~S}\right) \mathrm{m} / z$ (Calcd. $)=224.2442 \mathrm{Da} ; \mathrm{m} / z$ (Obs. $)=225.8140 \mathrm{Da}$.

5-(2-Hydroxyphenyl)-1,2,4-triazolidine-3-thione (3n): Product white crystalline, FT-IR: v 3444 (NH stretching), 3334 ( $\mathrm{NH}$ stretching), 3165 (CH stretching), 2987, 1646 (C=C stretching), 1535, 1472, 1361, 1282 (C=S stretching), 1202, 1119, 1045, 945, 826, 758, 621, $521 \mathrm{~cm}^{-1}$; ${ }^{1} \mathrm{H}-\mathrm{NMR}(400 \mathrm{MHz}$, DMSO- $\left.d_{6}\right): \delta 6.79(\mathrm{t}, 2 \mathrm{H}, \mathrm{ArH}, J=9 \mathrm{~Hz}), 7.24(\mathrm{~s}, 1 \mathrm{H}, \mathrm{CH}), 7.88(\mathrm{~m}, 2 \mathrm{H}, \mathrm{CH}), 8.21(\mathrm{~s}, 1 \mathrm{H}, \mathrm{NH}), 8.29$ $(\mathrm{s}, 1 \mathrm{H}, \mathrm{NH}), 9.94(\mathrm{~s}, 1 \mathrm{H}, \mathrm{OH}), 11.46(\mathrm{~s}, 1 \mathrm{H}, \mathrm{NH}) ;{ }^{13} \mathrm{C}-\mathrm{NMR}$ (DMSO-d $)$ : 115.2, 118.5, 121.3, 125.5, 132.3, 140.0, 154.4 and 176.0 ppm; HR-MS (ESI): $\left(\mathrm{C}_{8} \mathrm{H}_{9} \mathrm{~N}_{3} \mathrm{OS}\right) \mathrm{m} / z(\mathrm{Calcd})=.195.2451 \mathrm{Da} ; \mathrm{m} / z(\mathrm{Obs}$. $=195.1021 \mathrm{Da}$.

1,2,4-Triazospiroheptane-3-thione (5b):Product white crystalline, FT-IR: $v 3381$ (NH stretching), 3217 ( $\mathrm{NH}$ stretching), 2946 ( $\mathrm{NH}$ stretching), 1589 (C=C stretching), 1254 (C=S stretching), 1074, 856, 832 $\mathrm{cm}^{-1}$; ${ }^{1} \mathrm{H}-\mathrm{NMR}\left(400 \mathrm{MHz}, \mathrm{DMSO}-d_{6}\right): \delta 1.49-1.52\left(\mathrm{~m}, 4 \mathrm{H}, \mathrm{CH}_{2}\right), 1.61(\mathrm{~d}, 2 \mathrm{H}, J=6 \mathrm{~Hz}), 2.37-2.43(\mathrm{~m}$, $2 \mathrm{H}), 2.45-2.48\left(\mathrm{~s}, 2 \mathrm{H}, \mathrm{CH}_{2}\right), 7.58(\mathrm{~s}, 1 \mathrm{H}, \mathrm{NH}), 8.03(\mathrm{~s}, 1 \mathrm{H}, \mathrm{NH}), 9.68(\mathrm{~s}, 1 \mathrm{H}, \mathrm{NH}) ;{ }^{13} \mathrm{C}-\mathrm{NMR}$ (DMSO$\left.d_{6}\right): 29.0,32.2,34.8,35.4,41.4,44.0,44.2,44.4,44.6,44.8,45.0,45.2,164.4,183.6$ ppm; HR-MS $(\mathrm{ESI}):\left(\mathrm{C}_{8} \mathrm{H}_{15} \mathrm{~N}_{3} \mathrm{~S}\right) \mathrm{m} / z$ (Calcd. $)=185.2901 \mathrm{Da} ; \mathrm{m} / z$ (Obs. $)=186.0830 \mathrm{Da}$.

5'-Thioxospiro[indoline-3,3'-[1,2,4]-triazolidin]-2-one (5c): Product Yellow solid, FT-IR: v 3389 (NH stretching), 3274 (NH stretching), 3169, 1592, 1514, 1452, 1368, 1322, 1249 (C=S stretching), 1049, 895, 739, $584 \mathrm{~cm}^{-1} ;{ }^{1} \mathrm{H}-\mathrm{NMR}\left(400 \mathrm{MHz}, \mathrm{DMSO}-d_{6}\right): \delta 6.83$ (d, $\left.1 \mathrm{H}, \mathrm{ArH}, J=7.8 \mathrm{~Hz}\right), 7.21(\mathrm{t}, 1 \mathrm{H}, \mathrm{ArH}$, $J=7.5 \mathrm{~Hz}), 7.42(\mathrm{t}, 1 \mathrm{H}, \mathrm{ArH}, J=6.9 \mathrm{~Hz}), 7.72(\mathrm{~d}, 1 \mathrm{H}, \mathrm{ArH}, J=7.5 \mathrm{~Hz}), 8.29(\mathrm{~s}, 1 \mathrm{H}, \mathrm{NH}), 9.32(\mathrm{~s}, 1 \mathrm{H}$, $\mathrm{NH}), 11.81(\mathrm{~s}, 1 \mathrm{H}, \mathrm{NH}), 12.63(\mathrm{~s}, 1 \mathrm{H}, \mathrm{NH}) ;{ }^{13} \mathrm{C}-\mathrm{NMR}$ (DMSO- $\left.d_{6}\right): 111.5,120.5,121.4,122.9,131.7$, 132.5, 142.8, 163.1, 179.2 ppm; HR-MS(ESI): $\left(\mathrm{C}_{9} \mathrm{H}_{8} \mathrm{~N}_{4} \mathrm{OS}\right) \mathrm{m} / z($ Calcd. $)=220.0401 \mathrm{Da} ; \mathrm{m} / z$ (Obs. $)=$ $220.0131 \mathrm{Da}$.

1,2,4-Triazospiroctane-3-thione (5d): Product white crystalline, FT-IR: v 3434 (NH stretching), 2945 (NH stretching), 2856 ( $\mathrm{NH}$ stretching), 1587 (C=C stretching), $1273\left(\mathrm{C}=\mathrm{S}\right.$ stretching), $1010 \mathrm{~cm}^{-1} ;{ }^{1} \mathrm{H}-$ NMR (400 MHz, DMSO- $\left.d_{6}\right): \delta 1.45-1.47(\mathrm{t}, 2 \mathrm{H}, J=6 \mathrm{~Hz}), 1.58-1.59(\mathrm{~m}, 4 \mathrm{H}), 1.72-1.82(\mathrm{~m}, 4 \mathrm{H}), 2.33-$ $2.45(\mathrm{~m}, 4 \mathrm{H}), 6.50(\mathrm{~s}, 1 \mathrm{H}, \mathrm{NH}), 7.32(\mathrm{~s}, 1 \mathrm{H}, \mathrm{NH}), 8.57(\mathrm{~s}, 1 \mathrm{H}, \mathrm{NH}) ;{ }^{13} \mathrm{C}-\mathrm{NMR}$ (DMSO-d $)$ : 17.5, 27.4, 38.8, 72.8 and $184.2 \mathrm{ppm}$; HR-MS(ESI): $\left(\mathrm{C}_{9} \mathrm{H}_{17} \mathrm{~N}_{3} \mathrm{~S}\right) \mathrm{m} / z($ Calcd. $)=199.3684 \mathrm{Da} ; \mathrm{m} / z($ Obs. $)=199.4061$ Da. 
Waste to wealth: agro-waste catalyzed green method

\section{Results and Discussions}

Researchers from other laboratories and our own group described various novel agro-waste based solvent media for alternative greener and facile synthesis of various important organic transformations. In continuation of our effort to develop greener catalytic media, herein we have developed straightforward efficient, greener, inexpensive and high yielding protocol for the one-pot synthesis of 5-aryl-1,2,4-triazolidine-3-thione catalyzed by novel agro-waste WEOFSA is reported. Firstly, water extract of orange fruit shell ash is prepared by agro-waste of orange shells collected from the local; the shell is washed with distilled water, dried, and followed direct burning to ash using Bunsen flame. The burnt ash is soaked in double distilled water about $2 \mathrm{~h}$ and filtered, the resulted light brown colored water extract termed as a WEOFSA. The $\mathrm{pH}$ of the extract solution found to be 10.12. To explore the extracted WEOFSA as a catalytic solvent media for the synthesis of thiones is attempted. Initially started with $1 \mathrm{mmol}$ scale reaction of benzaldehyde with thiosemicarbazide as a model reaction in presence of WEOFSA under stirring at room temperature afford target product with $80 \%$ yield in 180 $\min$ (Scheme 1).

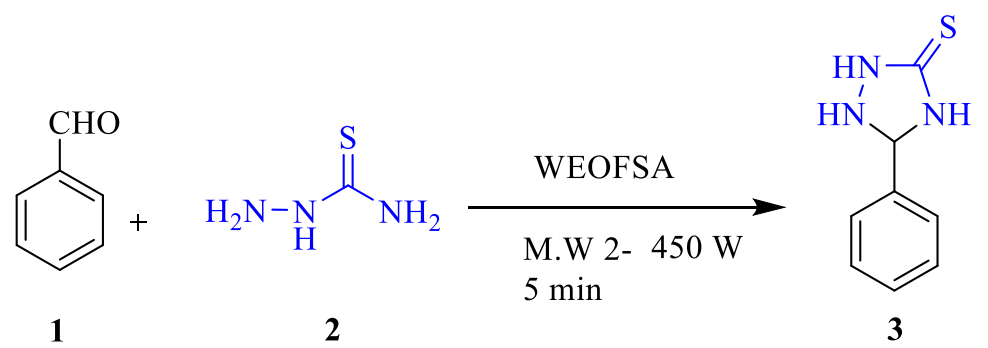

Scheme 1. Synthesis of 5-aryl-1,2,4-triazolidine-3-thiones

This preliminary model reaction indicated the reaction between aryl aldehyde with thiosemicarbazide proceed smoothly in the absence of organic solvent and catalyst. Further to examine the role of the agro-waste extract media and minimal volume required for the reaction, a series of reactions set-up (Table 1) and carried out in a model reaction in the absence of catalyst, and surprisingly no product separation observed even after $10 \mathrm{~min}$ of irradiation (S. No 1, Table1). Hence, it is confirmed that, the reaction required catalyst for the condensation followed by cyclization to form a desired product. For the minimum dose of solvent media required for the reaction, a model reaction chosen under optimized microwave irradiation power $(450 \mathrm{~W})$ with varied volume of WEOFSA by $0.5 \mathrm{~mL}$ interval from $1 \mathrm{~mL}$ to $4 \mathrm{~mL}$ in a separate reaction under microwave irradiation of $6 \mathrm{~min}$. The percentage product isolation with respect to change in agro-waste solvent media volume in $\mathrm{mL}$ is tabulated in Table 1. The optimized volume from experiment data reveled that, for $1 \mathrm{mmol}$ reaction required $3.5 \mathrm{~mL}$ of WEOFSA, the below volumes $(3.0,2.5,2.0 \ldots 1 \mathrm{~mL})$ gave lesser product yield, optimized volume 3.5 $\mathrm{mL}$ gave highest product isolation, and next volume higher $(4.0 \mathrm{~mL})$ ended with no change in product yield isolation.

Table 1. Optimization of WEOFSA in a model reaction

\begin{tabular}{cccc}
\hline S. No & WEOFSA $(\mathbf{m L})$ & Time $(\mathbf{m i n})$ & Yield (\%) \\
\hline $\mathbf{1}$ & - & $6-30$ & ND \\
$\mathbf{2}$ & 1.0 & 6 & 30 \\
$\mathbf{3}$ & 1.5 & 6 & 32 \\
$\mathbf{4}$ & 2.0 & 6 & 44 \\
$\mathbf{5}$ & 2.5 & 6 & 59 \\
$\mathbf{6}$ & 3.0 & 6 & 61 \\
$\mathbf{7}$ & 3.5 & 6 & 93 \\
$\mathbf{8}$ & 4.0 & 6 & 93 \\
\hline
\end{tabular}


Khatavi and Kantharaju Org. Commun. (2021) 14:3 240-254

To study the effect of temperature on the rate of the reaction as well as yield of the product, we carried out model reaction in a ultrasound and microwave irradiation using WEOFSA. It is observed, the reaction under microwave and ultrasound assisted proceeds reaction very smoothly with increased yield isolation in shorter reaction time compared to the conventional method (Table 2). The optimized reaction method revealed that, microwave accelerated reaction go product formation very faster as compared to other two methods (S. No. 1 and 2, Table 2). To check the required optimum microwave power for the reaction, we have carried

Table 2. Optimization of different reaction methods

\begin{tabular}{cccc}
\hline S. No & Methods & Time (min) & Yield (\%) \\
\hline $\mathbf{1}$ & Stirring@ RT & $60-180$ & $75-80$ \\
$\mathbf{2}$ & Ultra-sonication & $30-40$ & $79-81$ \\
$\mathbf{3}$ & Microwave irradiation & $2-6$ & $90-93$ \\
\hline
\end{tabular}

out reaction in a model reaction with optimized agro-waste media $(3.5 \mathrm{~mL})$ by varying microwave power available in a custom-made microwave oven with a measure of temperature after each power irradiation (Table 3). The optimized microwave power at $450 \mathrm{~W}$ with exposure time of $6 \mathrm{~min}$ gave highest product isolation compared to low power of 100, 180 and $300 \mathrm{~W}$. Further increased power $600 \mathrm{~W}$ showed no change in the product yield isolation or reaction time. Hence, the optimized microwave power for the 5aryl-1,2,4-triazolidine-3-thiones synthesis used in the present method is $450 \mathrm{~W}$ with exposure time of 6 min.

Table 3. Optimization of microwave power

\begin{tabular}{ccccc}
\hline S. No. & $\begin{array}{c}\text { Microwave } \\
\text { Power }(\mathbf{W})\end{array}$ & $\begin{array}{c}\text { Temperature } \\
\text { generated }\left({ }^{\circ} \mathbf{C}\right)\end{array}$ & Time (min) & Yield (\%) \\
\hline $\mathbf{1}$ & 100 & 78 & 6 & 20 \\
$\mathbf{2}$ & 180 & 96 & 6 & 32 \\
$\mathbf{3}$ & 300 & 104 & 6 & 85 \\
$\mathbf{4}$ & $\mathbf{4 5 0}$ & $\mathbf{1 3 0}$ & $\mathbf{6}$ & $\mathbf{9 3}$ \\
$\mathbf{5}$ & 600 & 142 & 6 & 93 \\
\hline
\end{tabular}

To evaluate the present method substrate scope, a variety of substituted aromatic aldehydes are reacted with thiosemicarbazide under optimized reaction condition to afford corresponding 5-aryl-1,2,4triazolidine-3-thiones in good to excellent yield Table 4. Aromatic aldehyde bearing electron donating $\mathbf{3 h}$ and $\mathbf{3 o}$, and withdrawing groups $\mathbf{3 b}, \mathbf{3 c}$ and $\mathbf{3 d}$ were converted into their corresponding triazolidine3 -thiones with excellent yields of $87-93 \%$. From the experimental results we conclude that, there is no measurable EDG (electron donating) and EWG (electron withdrawing) substituent role on the rate of reaction and isolation of yield, and most of the reaction completed in a shorter reaction time with negligible difference in their product yield. It is worth to share our experience to this reaction that, the reaction work-up found easier and it involves simple filtration gave pure targeted product are listed in Table 4. 
Waste to wealth: agro-waste catalyzed green method

Table 4. Synthesis of 5-aryl-1,2,4-triazolidine-3-thiones and physical data

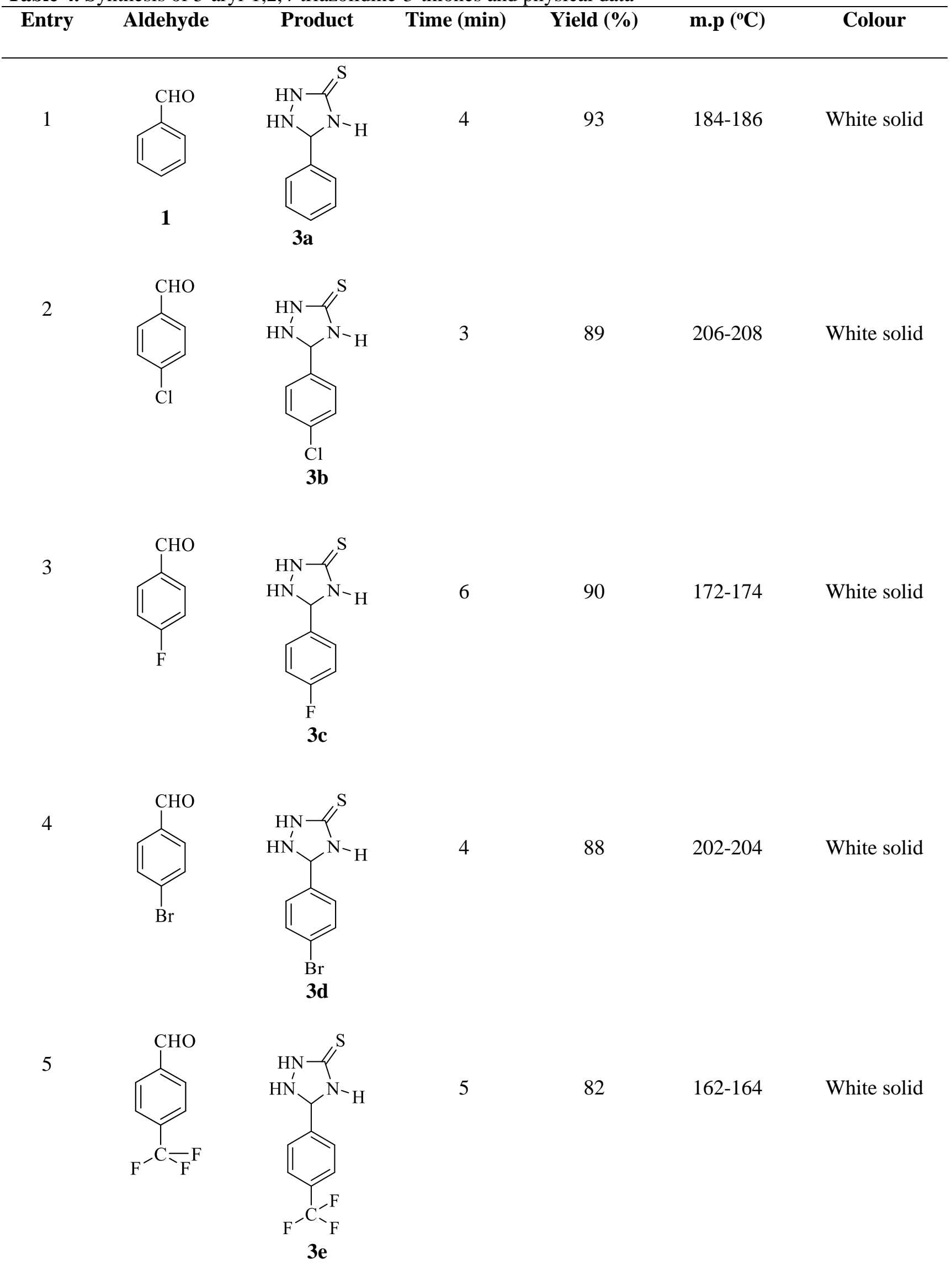


Khatavi and Kantharaju Org. Commun. (2021) 14:3 240-254

Table 4. continued..

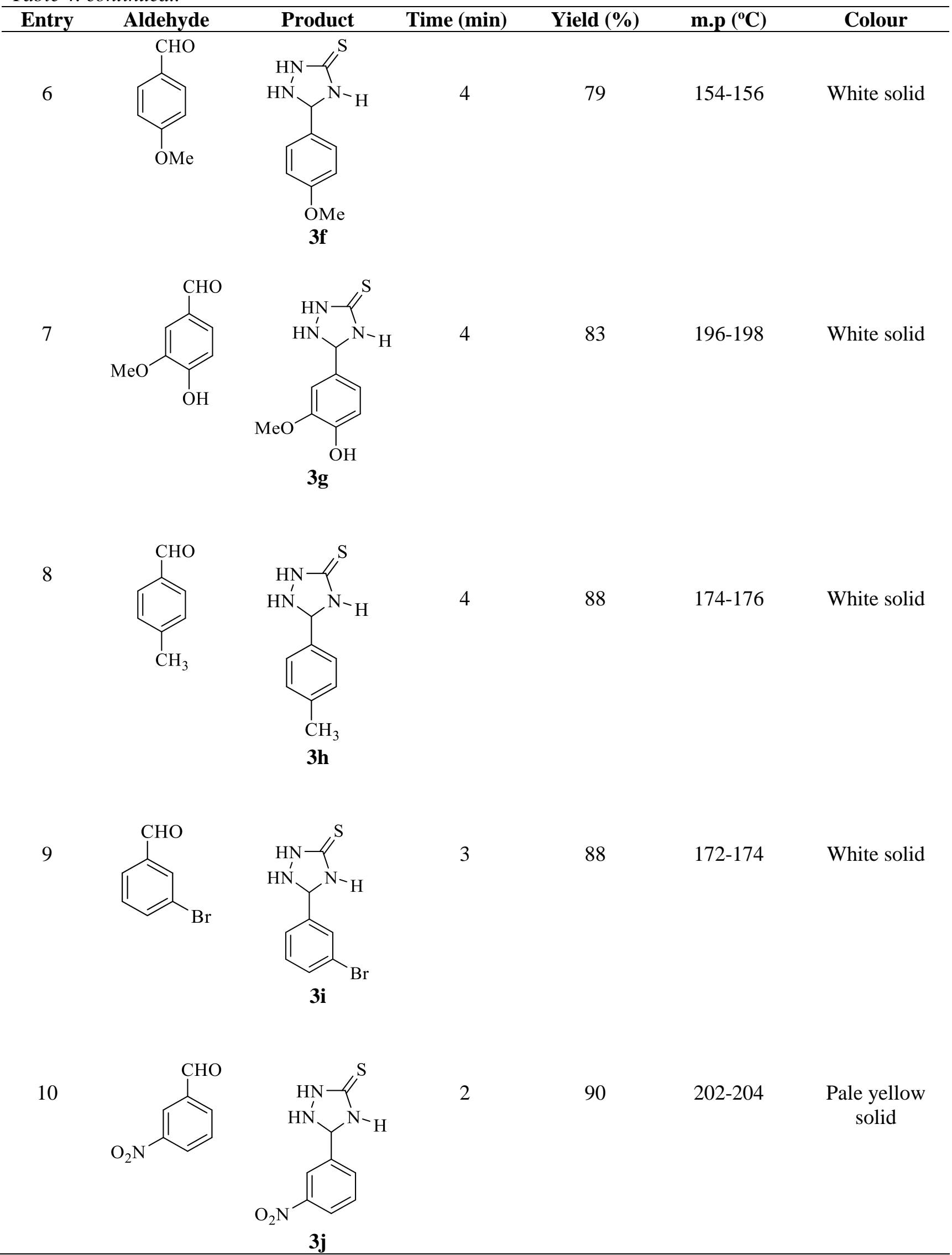


Waste to wealth: agro-waste catalyzed green method

Table 4. continued.

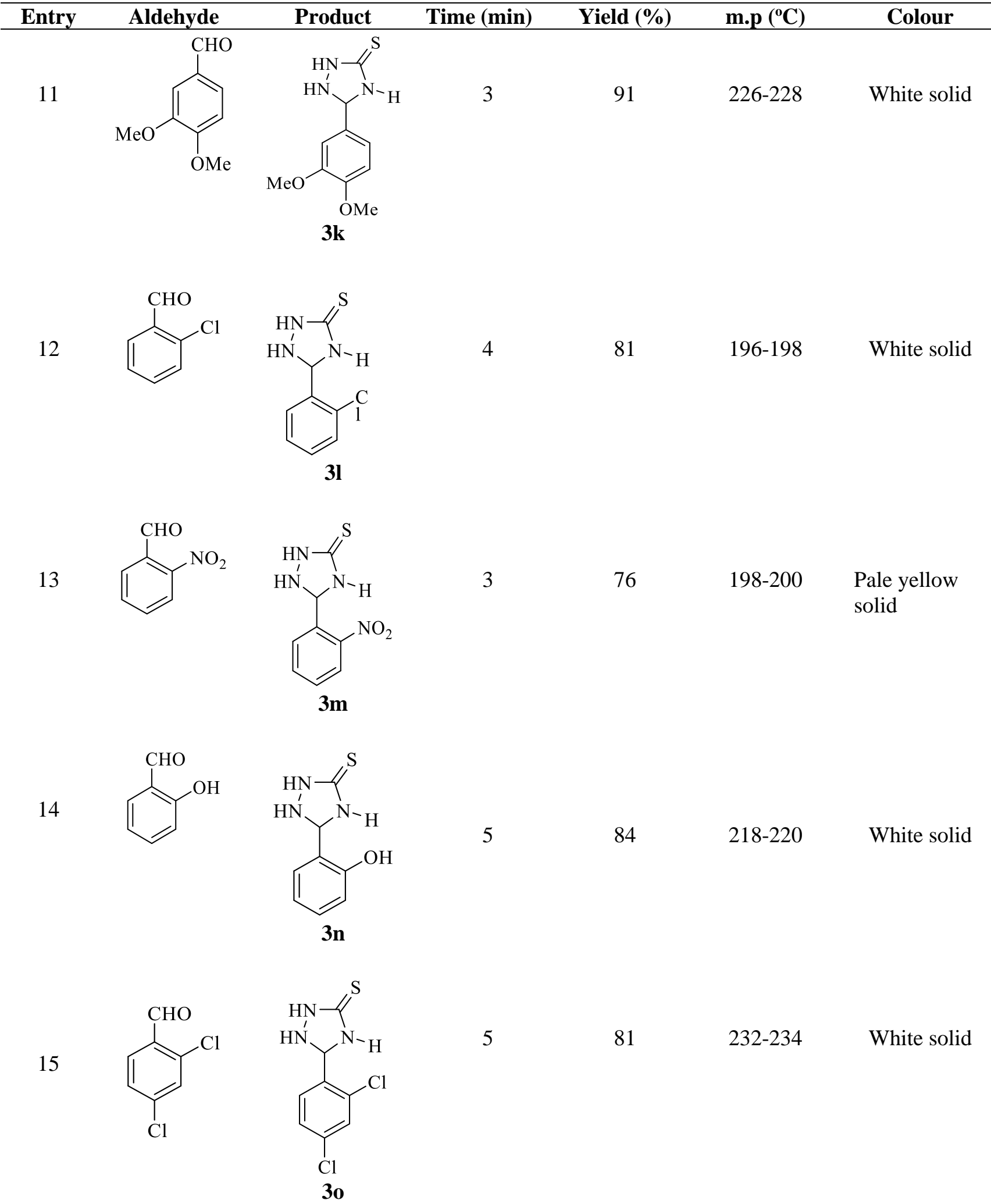


Khatavi and Kantharaju Org. Commun. (2021) 14:3 240-254

\begin{tabular}{cccccc}
\hline Table 4. continued.. & Time (min) & Yield (\%) & m.p ( $\left.{ }^{\circ} \mathbf{C}\right)$ & Colour \\
\hline Entry & Aldehyde & Product & Tellow solid \\
\hline
\end{tabular}

Excited by the present method, we further extended to substrate cyclic ketone in place of aromatic aldehyde in a model reaction with all optimized above reaction condition followed (Scheme 2). Notably, the reaction proceeded very smoothly with product isolated in excellent yield (Table 5). It is worth to

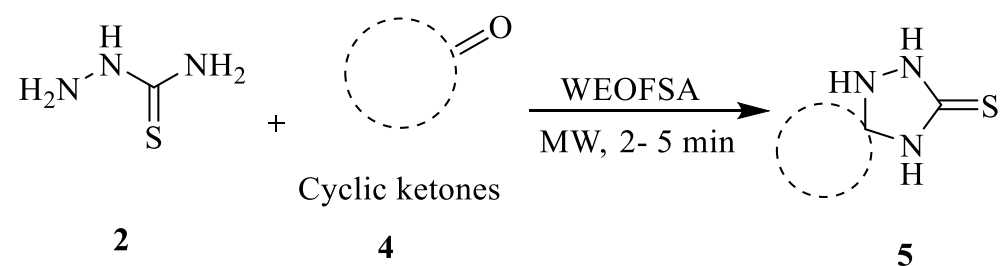

Scheme 2. Synthesis of 1,2,4-triazospiro-3-thiones

state that, the substituted derivatives captivated spirocentre viasimple green protocol transformation gave to access bicyclic units in a highly efficient manner. The experimental observation of the above studies clearly indicated that, the present agro-waste catalyzed reaction can be applied to build library of 1,2,4-triazolidine-3-thiones and 1,2,4-triazaspiro[5.4]-hexanone-3-thione scaffolds.

The molecular structure and purity of the synthesized compounds are established by using various spectroscopic techniques. To analyze compound 5-aryl-1,2,4-triazolidine-3-thiones 3c (Table 4) taken for complete spectral analysis. The FT-IR spectrum of $\mathbf{3 c}$ showed prominent stretching bands at 3286 and $3185 \mathrm{~cm}^{-1}$ are due to the NH stretching, band at $1686 \mathrm{~cm}^{-1}$ due to $\mathrm{C}=\mathrm{C}$ and band at $1227 \mathrm{~cm}^{-1}$ is due to $-\mathrm{C}=\mathrm{S}$ (Figure $\mathrm{S} 1$ ); ${ }^{1} \mathrm{H}-\mathrm{NMR}(\delta)$ in DMSO- $d_{6}$ showed different peaks at 7.19-7.23 doublet due to $2 \mathrm{H}$ of $\mathrm{ArH}$, multiplet at 7.83-7.86 is due to $2 \mathrm{H}$ of $\mathrm{ArH}$, singlet at 8.00 due to $1 \mathrm{H}$ of $\mathrm{CH}$, singlets at 8.00, 8.17 and 11.40 due to $\mathrm{NH}$ protons (Figure S2); ${ }^{13} \mathrm{C}-\mathrm{NMR}$ : 116.0, 116.2, 129.9, 130.0, 131.3, 141.8, 162.2, 164.7 and $178.5 \mathrm{ppm}$ (Figure S3) and mass spectrometry confirm the molecular weight $\mathrm{m} / \mathrm{z}$ $($ Calcd. $)=197.0943 \mathrm{Da} ; \mathrm{m} / z($ Obs. $)=196.0371 \mathrm{Da}($ Figure S4).

The formation of a novel 1,2,4-triazaspiro[5.4]hexanone-3-thione 5a (Table 5) was confirmed by various spectral techniques. FT-IR shows prominent bands at 3380,3216 and $3145 \mathrm{~cm}^{-1}$ are due to the NH stretching, band at $2940 \mathrm{~cm}^{-1} \mathrm{CH}$ stretching, band at $1245 \mathrm{~cm}^{-1}$ is due to $-\mathrm{C}=\mathrm{S}$ (Figure S9); ${ }^{1} \mathrm{H}-$ NMR $(\delta)$ in DMSO- $d_{6}$ shows different peaks at $\delta$ 1.52-1.58 multiplet due to $6 \mathrm{H}, 2.17-2.20$ multiplet due 
Waste to wealth: agro-waste catalyzed green method

to $2 \mathrm{H}$, $-\mathrm{CH}_{2}$, peak at 2.37-2.48 doublet due to $2 \mathrm{H}$, $-\mathrm{CH}_{2}$, peaks at $7.49,7.94$ and at 10.13 singlet due to $\mathrm{NH}$ protons (Figure S10); ${ }^{13} \mathrm{C}-\mathrm{NMR}$ shows prominent peaks in DMSO- $d_{6}$ solvent are 25.5, 26.2, 27.4, 27.6, 35.4, 39.4, 39.6, 39.8, 40.0, 40.2, 40.4, 40.6, 157.4 and 179.0 ppm (Figure S11); HR-MS(ESI): $\mathrm{m} / z($ Calcd. $)=171.2601 \mathrm{Da} ; \mathrm{m} / z($ Obs. $)=172.0887[\mathrm{M}+\mathrm{H}]^{+} \mathrm{Da}($ Figure S12).

Table 5. Synthesis of 5-aryl-1,2,4-triazospiro-3-thiones and its physical constants

Entry Cyclic ketones

Further, we compared present agro-waste catalytic solvent media demonstrated with various literature reported methods for the 5-aryl-1,2,4-triazolidine-3-thiones and 5-aryl-1,2,4-triazospiro-3thiones synthesis. Namely, expensive magnetically separable heterogeneous catalyst $\mathrm{CoFe}_{2} \mathrm{O}_{4} @ \mathrm{SiO}_{2}$ employed in the synthesis and reaction completed in faster manner gave $98 \%$ yield (entry 1 , Table 6$)^{53}$. Reaction carried out in a $25 \%$ ethanol under room temperature stirring condition and completed in 15 min afford $95 \%$ yield (entry 2, Table 6) ${ }^{54}$. Reaction in the presence of ionic liquid $\left[(\mathrm{Py})_{2} \mathrm{SO}_{[}\left[\mathrm{HSO}_{4}\right]\right.$ was carried out and taken longer reaction time of about 60 min with $75 \%$ yield (entry 3, Table 6) ${ }^{55}$. 
Khatavi and Kantharaju Org. Commun. (2021) 14:3 240-254

Another research group reported PEG-400 accelerated synthesis required elevated temperature for about $12 \mathrm{~min}$ to complete the reaction (entry 4, Table 6) ${ }^{42,43}$. Synthesis catalyzed in $80 \%$ of $\mathrm{CH}_{3} \mathrm{COOH}$ required $30 \mathrm{~min}$ for the conversion of all reactants into product with $90 \%$ yield (entry 5 , Table 6 ) ${ }^{56}$. The multicomponent reaction in one-pot in the presence of ionic liquid (glycine nitrate) required $4 \mathrm{~h}$ for the completion of the reaction and the method took long reaction time compared above discussed methods with $88 \%$ yield (entry 6 , Table 6$)^{57}$. The sulfamic acid catalyzed reaction afford product after the reflux temperature of reactants for about $30 \mathrm{~min}$ (entry 7, Table 6) ${ }^{58}$. So, it is revealed that, there are number of reported protocols suffering from various limitations, to overcome some of these, we have demonstrated a simple, inexpensive and greener protocol for the synthesis of valuable 1,2,4-triazolidine3-thiones derivatives (entry 8, Table 6).

Table 6. Comparison of reported with present method

\begin{tabular}{clcc}
\hline Entry & \multicolumn{1}{c}{ Catalyst } & Time (min) & Yield (\%) \\
\hline 1 & $\mathrm{CoFe}_{2} \mathrm{O}_{4} @ \mathrm{SiO}_{2} @$ r.t & 10 & 98 \\
2 & $25 \%$ Ethanol@ r.t & 15 & 95 \\
3 & {$\left[(\mathrm{Py})_{2} \mathrm{SO}\right]\left[\mathrm{HSO}_{4}\right]$} & 60 & 75 \\
4 & $\mathrm{PEG}-400 @ 80{ }^{\circ} \mathrm{C}$ & 12 & 97 \\
5 & $80 \% \mathrm{CH}_{3} \mathrm{COOH}$ & 30 & 90 \\
6 & Glycinenitrate @ 80 ${ }^{\circ} \mathrm{C}$ & 240 & 88 \\
7 & Sulfamic acid, Ethanol, Reflux & 30 & 92 \\
8 & WEOFSA, MW 450 W (Present method) & $\mathbf{2 - 5}$ & $\mathbf{9 3}$ \\
& & & \\
\hline
\end{tabular}

\section{Conclusion}

The present method is successfully demonstrated the synthesis of 5-aryl-1,2,4-triazolidine-3thiones and 5-aryl-1,2,4-triazospiro-3-thiones in the presence of agro-waste derived WEOFSA as greener catalytic media. The developed method is added advantages like not required external base, inexpensive, environment friendly, moderate to excellent yield isolation in a simple method. The isolated product is found chromatographically pure and are analyzed by using various spectroscopic techniques FT-IR, ${ }^{1} \mathrm{H}-,{ }^{13} \mathrm{C}-\mathrm{NMR}$ and HR-MS.

\section{Acknowledgement}

Authors thankful to the UGC for the award of Major Research Project \{(UGC-MRP: F.43181/2014 (SR)\} and VGST, Govt. of Karnataka for SMYSR award to Dr. KK. The author is also acknowledging Department of Science and Technology for the award of DST-FIST programme to the Department of Chemistry, RCUB.

\section{Supporting information}

Supporting information accompanies this paper on http://www.acgpubs.org/journal/organiccommunications

\section{ORCID}

Santosh Y. Khatavi: 0000-0003-2324-6508

Kantharaju Kamanna: 0000-0002-4696-5401 
Waste to wealth: agro-waste catalyzed green method

\section{References}

[1] Garrido-Castro, A. F.; Salaverri, N.; Maestro, M. C.; Aleman, J. Intramolecular homolytic substitution enabled by photoredox catalysis: sulfur, phosphorus, and silicon heterocycle synthesis from aryl halides. Org. Lett. 2019, 21, 5295-5300.

[2] Taylor, A. P.; Robinson, R. P.; Fobian, Y. M.; Blakemore, D. C.; Jones, L. H.; Fadeyi, O. Modern advances in heterocyclic chemistry in drug discovery. J. Med. Chem. 2014, 57, 5845-5859;

[3] Baumann, M.; Baxendale, I. R. An overview of the synthetic routes to the best-selling drugs containing 6membered heterocycles. Beilstein J. Org. Chem. 2013, 9, 2265-2319.

[4] Kharb, K.; Chander, P.; Sharma Shahar, Y. M. Pharmacological significance of triazole scaffold. J. Enzyme Inhib. Med. Chem. 2011, 26, 1-21.

[5] Dheer, D.; Singh, V.; Shankar, R. Medicinal attributes of 1,2,3-triazoles: Current developments. Bioorg. Chem. 2017, 71, 30-54.

[6] Naito, Y.; Akahoshi, F.; Takeda, S.; Okada, T.; Kajii, M.; Nishimura, H.; Sugiura, M.; Fukaya, C.; Kagitani, Y. Synthesis and pharmacological activity of triazole derivatives inhibiting eosinophilia. J. Med. Chem., 1996, 39, 3019-3029.

[7] Shafran, E. A.; Bakulev, V. A.; Rozin, Y. A.; Shafran, Y. M. Condensed 1,2,3-triazoles (Review). Chem. Heterocycl. Compd. 2008, 44, 1040-1069.

[8] Creary, X.; Anderson, A.; Brophy, B.; Crowell, F.; Funk, Z. Method for assigning structure of 1,2,3triazoles. J. Org. Chem. 2012, 77, 8756-8761.

[9] Patil, S. B.; Krishnamurthy, G.; Shashikumar, N. D.; Lokesh, M. R.; Bhojya Naik, H. S. Synthesis and antimicrobial activity of some [1,2,4]-triazole derivatives. J. Chem., 2013, 1, 1-7.

[10] Kahnberg, P.; Lager, E.; Rosenberg, C.; Schougaard, J.; Camet, L.; Sterner, O.; Ostergaard, E. N.; Nielsen, M.; Liljefors, T. Refinement and evaluation of a pharmacophore model for flavone derivatives binding to the benzodiazepine site of the GABA receptor. J. Med. Chem. 2002, 45, 4188-4201.

[11] Cheng, H.; Wan, J.; Lin, M.; Liu, Y.; Lu, X.; Liu, J.; Xu, Y.; Chen, I.; Tu, Z.; Yih-Shyun, E. C.; Ding, K. design, synthesis, and in vitro biological evaluation of 1h-1,2,3-triazole-4-carboxamide derivatives as new anti-influenza a agents targeting virus nucleoprotein. J. Med. Chem. 2012, 55, 2144-2153.

[12] Aneja, B.; Azam, M.; Alam, S.; Perwez, A.; Maguire, R.; Yadava, U.; Kavanagh, K.; Daniliuc, G. C.; Rizvi, A. M. M.; Mohd, Q.; Haq, R.; Abid, M. natural product-based 1,2,3-triazole/sulfonate analogues as potential chemotherapeutic agents for bacterial infections. ACS Omega, 2018, 3, 6912-6930.

[13] Boechat, N.; Ferreira, V. F.; Ferreira, S. B. Lourdes M.; Ferreira, G.; Fernando, C. S. Bastos, M. M.; Costa, M. S.; Lourenc, M. C. S.; Pinto, A. C.; Krettli, A. U.; Aguiar, A. C.; Teixeira, B. M.; Silva, N. V.; Martins, P. R. C.; Flavio, A. F. M.; Bezerra, A. L. S. C.; Gerson, P. S.; Costa, C. C. P. Novel 1,2,3-triazole derivatives for use against Mycobacterium tuberculosis $\mathrm{H}_{37} \mathrm{Rv}$ (ATCC 27294) strain. J. Med. Chem. 2011, 54, 59885999.

[14] Lestner, J.; Hope, W. W. Itraconazole: an update on pharmacology and clinical use for treatment of invasive and allergic fungal infections. Expert Opin. Drug Metab. Toxicol. 2013, 9, 911-926.

[15] Egunsola, O., Adefurin, A., Fakis, A., Jacqz-Aigrain, E., Choonara, I., Sammons, H. Eur. J. Clin. Pharmacol. 2013, 69, 1211-1221.

[16] Butters, M.; Ebbs, J.; Green, S. P.; Macrae, J.; Morland, M.C.; Murtiashaw, C.W.; Pettman, A. Process development of voriconazole: a novel broad-spectrum triazole antifungal agent. J. Org. Proces. Res. \& Dev. 2001, 5, 28-36.

[17] Pyeon, T.; Chung, S.; Kim, I.; Lee, S.; Jeong, S. The effect of triazolam premedication on anxiety, sedation, and amnesia in general anesthesia. Korean J. Anesthesiol. 2011, 70, 292-298.

[18] Ait-Daoud N.; Hamby, A. S.; Sharma, S.; Blevins, D. A review of alprazolam use, misuse, and withdrawal. J. Addict. Med. 2018, 12, 4-10.

[19] Nishii, S.; Hori, H.; Kishimoto, T.; Nakamura, J. A successful case of dose reduction in etizolam dependence using fine granules: a case report. Int. Med. Case Rep. J. 2014, 7, 121-122.

[20] Murty, M. S. R.; Ram, K. R.; Ramalingeswara Rao, B.; Venkateswara Rao, R.; Mohana Rao, K.; Venkateswara Rao, J.; Pamanji, R.; Velatooru, L. R. Synthesis, characterization, and anticancer studies of $\mathrm{S}$ and $\mathrm{N}$ alkyl piperazine-substituted positional isomers of 1,2,4-triazole derivatives. Med. Chem. Res. 2014, 23, 1661-1671.

[21] Mir, F.; Shafi, S.; Zaman, M. S.; Kalia, N. P.; Rajput, V. S.; Mulakayala, C.; Mulakayala, N.; Khan, I. A.; Alam, M. S. Sulfur rich 2-mercaptobenzothiazole and 1,2,3-triazole conjugates as novel antitubercular agents. Eur. J. Med. Chem. 2014, 76, 274-283.

[22] Molkere, B. B.; Veerabhadraswamy, M.; Karunakar, P. Synthesis and evaluation of biological activities of triazoles. J. Pharm. Chem. Biol. Sci. 2017, 4, 512-521. 
Khatavi and Kantharaju Org. Commun. (2021) 14:3 240-254

[23] Mabkhot, Y. N.; Barakat, A.; Al-Majid, A. M.; Alshahrani, S.; Yousuf, S.; Choudhary, M. I. Synthesis, reactions and biological activity of some new Bis-heterocyclic ring compounds containing sulphur atom. Chem. Cent. J. 2013, 7, 112.

[24] Asif, M. Biological potentials of biological active triazole derivatives: a short review Org. Chem. Curr. Res. 2016, $5,1-8$.

[25] Martins, P.; Jesus, J.; Santos, S.; Raposo, L. R.; Roma-Rodrigues, C.; Baptista, P. V.; Fernandes, A. R. Heterocyclic anticancer compounds: recent advances and the paradigm shift towards the use of nanomedicines. Molecules 2015, 20, 16852-16891.

[26] Shaker, The chemistry of mercapto- and thione-substituted 1,2,4-triazoles and their utility in heterocyclic synthesis. Arkivoc 2006, 6, 59-112.

[27] Pignatellol, S. M. R.; Panicol, A. M.; Mazzonel, G.; Pennisi, G.; Castana, M. M. R.; Blandin, G. Synthesis and biological evaluation of thiazolo-triazole derivatives. Eur. J. Med. Chem. 1991, 26, 929-938.

[28] Llona-Minguez, S., Hoglund, A.; Wiita, W.; Almlof, I.; Mateus, A.; Manuel, C.; Cindy, E.; Homan, O. L.; Baranczewski, P.; Jemth, A-S.; Haggled, M.; Martens, U.; Lundgren, B.; Artursson, P.; Lundback, T.; Jenmalm, J. A.; Berglund, W. U.; Scobie, M.; Helleday, T. Identification of triazolothiadiazoles as potent inhibitors of the dctp pyrophosphatase. J. Med. Chem. 2017, 2148-2154.

[29] Khan, I.; Ibrar, A.; Abbas, N. Triazolothiadiazoles and triazolothiadiazines-biologically attractive scaffolds. Eur. J. Med. Chem. 2013, 63, 854-868.

[30] Siddiqui, N. J.; Idrees, M.; Khati, N. T.; Dhonde, G. M. Synthesis of novel bridgehead heterocycles via cyclization of 4-amino-1,2,4- triazole-3(4H)-thiones and their antimicrobial screening. Der Chemica. Sinic. 2015, 6, 49-54.

[31] Gupta, P.; Mahajan, A. Green chemistry approaches as sustainable alternatives to conventional strategies in pharmaceutical industry. RSC Adv. 2015, 5, 26686-26705.

[32] Baumann, M.; Baxendale, I. R.; Kuratli, C.; Ley, S. V.; Martin, R. E.; Schneider, J. Synthesis of a druglike focused library of trisubstituted pyrrolidines using integrated flow chemistry and batch methods. ACS Comb. Sci. 2011, 13, 405-413.

[33] Tucker, J. L. Green chemistry, a pharmaceutical perspective. Org. Process. Res. Dev. 2006, 10, 315-319.

[34] Panda, S. S.; Jain, S. C. "in water" syntheses of heterocyclic compounds. Mini-Rev. Org. Chem. 2011, 8, 455-464.

[35] Tasqeeruddin, S.; Asiri, I. Y. An environmentally benign, green, and efficient ionic liquid catalyzed synthesis of Quinoline derivatives via Knoevenagel condensation. J. Heterocycl. Chem. 2020, 57, 132-139.

[36] Sarmah, M.; Mondal, M.; Bora, U. Agro-waste extract-based solvents: emergence of novel green solvent for the design of sustainable processes in catalysis and organic chemistry. Chem. Select, 2017, 2, 51805188.

[37] Tanaka, K.; Toda, F. Solvent-free organic synthesis. Chem. Rev. 2000, 100, 1025-1074.

[38] Zhang, M.; Fu, Q-Y.; Gao, G.; He, H-Y.; Zhang, Y.; Wu, Y-S.; Zhang, Z-H. Catalyst-free, visible-light promoted one-pot synthesis of spirooxindole-pyran derivatives in aqueous ethyl lactate. ACS Sustain. Chem. Eng. 2017, 5, 6175-6182.

[39] Basumatary, S.; Nath, B.; Kalita, P. Application of agro-waste derived materials as heterogeneous base catalysts for biodiesel synthesis. J. Renew. Sustain. Energy 2018, 10 043105-18.

[40] Bennett, J. A.; Wilson, K.; Lee, A. F. Catalytic applications of waste derived materials. J. Mater. Chem. A. 2016, 4, 3617-3637.

[41] Calo, V.; Nacci, A.; Monopoli, A.; Fornaro, A.; Sabbatini, L.; Cioffi, N.; Ditaranto, N. Heck reaction catalyzed by nanosized palladium on chitosan in ionic liquids. J. Organomet. 2004, 23, 5154-5158.

[42] Hassan, A. A.; Shawky, A. M. Thiosemicarbazides in heterocyclization. J. Heterocycl, Chem. 2011, 48, $495-516$

[43] Ramesh, R.; Lalitha, A. PEG-assisted two-component approach for the facile synthesis of 5-aryl-1,2,4triazolidine-3-thiones under catalyst-free conditions. RSC Adv. 2015, 5, 51188-51192.

[44] Guo, Z. The modification of natural products for medical use. Acta Pharm. Sin. B. 2017, 7, 119-136.

[45] Mu, J-X.; Zhai, Z-W.; Tan, C-X.; Weng, J-Q.; Wu, H-K.; Duke, S-O.; Zhang, Y-G.; Liu, X-H. Synthesis and Herbicidal Activity of 1,2,4-Triazole Derivatives Containing a Pyrazole Moiety. J. Heterocycl. Chem. 2019, 56, 968-971.

[46] Katica, C-R.; Vesna, D.; Kakurinov, V.; Molnar, D. G.; Aleksandra, B. Synthesis, antibacterial and antifungal activity of 4-aubstituted-5-Aryl-1,2,4-triazoles. Molecules 2001, 9, 815-824.

[47] Ahirwar, J.; Ahirwar, D.; Lanjhiyana, S.; Jha, A. K. Synthesis and characterization of 1,2,4-triazole-pyridine hybrids as potential antimicrobial agents. Int. J. Pharmaceut. Clin. Res. 2017, 9, 702-709.

[48] Mariam, A-S.; Hanadi, Y.M.; Kamal, U.S.; Ramadan, A. M. Synthesis and spectroscopic properties of new azo dyes derived from 3-ethylthio-5-cyanomethyl-4-phenyl-1,2,4-triazole. Molecules 2014, 19, 29933003. 
Waste to wealth: agro-waste catalyzed green method

[49] El Ashry, E. S.; EL-Rafey, E.; Rezki, N.; Abou-Elnaga, H. H.; Wedad, M. A. B.; Boghdadi, Y. M. Evaluation of some functionalized imidazoles and 1,2,4-triazoles as antioxidant additives for industrial lubricating oils and correlating the results with the structures of additives using empirical AM1 calculations. J, Saud. Chem. Soc. 2014, 18, 443-449.

[50] Lebrini, M.; Traisnel, M.; Lagrene, M.; Mernari, B.; Bentiss, F. Inhibitive properties, adsorption and a theoretical study of 3,5-bis(n-pyridyl)-4-amino-1,2,4-triazoles as corrosion inhibitors for mild steel in perchloric acid. Corros. Sci. 2008, 50 473-479.

[51] Mali, D. A.; Telvekar, V. N. Synthesis of triazolidines and triazole using DMAP. Synth. Commun. 2016, 47, 324-329.

[52] Othman, A. A.; Kihel, M.; Amara, S. 1,3,4-oxadiazole, 1,3,4-thiadiazole and 1,2,4-triazole derivatives as potential antibacterial agents. Arab. J. Chem. 2009, 21, 1660-1675.

[53] Kantharaju, K.; Khatavi, S. Y. Microwave accelerated synthesis of 2-amino-4h -chromenes catalyzed by welfsa: a green protocol. Chem. Select. 2018, 3, 5016-5024.

[54] Pansambal, S. S.; Ghotekar, S. K.; Shewale, S. S.; Deshmukh, K. K.; Barde, N. P., Bardapurkar, P. P. Efficient synthesis of magnetically separable $\mathrm{CoFe}_{2} \mathrm{O}_{4} @ \mathrm{SiO}_{2}$ nanoparticles and its potent catalytic applications for the synthesis of 5-aryl-1,2,4-triazolidine-3-thione derivatives. J. Water Environ. Nanotechnol. 2019, 4, 174-186.

[55] Ramesh, R.; Lalitha, A. Facile and green chemistry access to 5-aryl-1,2,4-triazolidine-3-thiones in aqueous medium. Chem. Select. 2016, 1, 2085-2089.

[56] Patil, P. B.; Patil, J. D.; Korade, S. N.; Kshirsagar, S. D.; Govindwar, S. P.; Pore, D. M. An efficient synthesis of anti-microbial 1,2,4-triazole 3-thiones promoted by acidic ionic liquid. Res. Chem. Intermed. 2016, 42, 4171-4180.

[57] Jadhav, V. D.; Bholay, A. D.; Gaikwad, S.; Mahale, K. A.; Patil, P. S.; Jadhav, G. R.; Gaikwad, V. B. Simple and green way to synthesis 5-aryl-1,2,4-triazolidine-3-ones in aqueous medium. Int. J. Chem. Physic. Sci. 2018, 7, 119-132.

[58] Mane, M. M.; Pore, D. M. A novel one pot multi-component strategy for facile synthesis of 5-aryl-[1, 2, 4]triazolidine-3-thiones. Tetrahedron Lett. 2014, 55, 6601-6604.

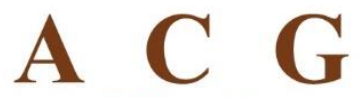

publications

(C) 2021 ACG Publications 